\title{
Prevalence of malocclusions in the 13-20-year-old categories of football athletes
}

\section{Luci Alves de Souza(a) Thais Regina Elmadjian ${ }^{(a)}$ \\ Reinaldo Brito e Dias ${ }^{(b)}$ \\ Neide Pena Coto(b)}

(a) School of Dentistry of the Universidade de São Paulo, São Paulo, SP, Brazil.

(b) Department of Surgery, Maxillo Facial Prosthesis and Traumatology, School of Dentistry of the Universidade de São Paulo, São Paulo, SP, Brazil.

\section{Corresponding author:}

Luci Alves de Souza

Faculdade de Odontologia da Universidade de São Paulo

Departamento de Cirurgia, Prótese e

Traumatologia Maxilo Faciais

Avenida Lineu Prestes, 2227 - Cidade

Universitária

São Paulo - SP - Brazil

CEP: 05508-000

E-mail: luci.souza@usp.br

Received for publication on Aug 20, 2010 Accepted for publication on Sep 28, 2010

\begin{abstract}
The dentist can offer athletes improvement in their physical performance through the maintenance of oral health, preventing and treating any and all changes in the stomatognathic system, such as dental malocclusions, that compromise the athletes' performance. The objective of this study is to research the presence of dental malocclusions in athletes of the category between 13 and 20 years of age, from the São Paulo Football Club. 84 athletes participated in this study, dealing with the following topics: molar relation (Angle's classification); presence of overbite; underbite; overcrowding; abnormal spacing; open bite; and anterior, posterior, bilateral and unilateral crossbite; midline deviation and facial type (mesofacial, brachyfacial and dolichofacial). Only one table was made, showing percentages. In regard to Angle's molar relation, $89 \%$ are in Class I, $8 \%$ in Class II, 3\% Class III, 9\% of the athletes had overbite, $4 \%$ had underbite, $13 \%$ had overcrowding and $21 \%$ had abnormal spacing. In regard to the bite, $11 \%$ presented anterior open bite. In regard to crossbite, $7 \%$ presented unilateral crossbite on the right side and $2 \%$ on the left side; $5 \%$ presented posterior crossbite and $4 \%$ anterior crossbite. In regard to midline deviations, $4 \%$ presented deviation in the maxilla and $33 \%$ in the mandible. In regard to facial type: $39 \%$ are dolichofacial, $4 \%$ brachyfacial and $57 \%$ mesofacial. Based on the results shown, proposals for the implementation of dental, phoniatric, and Ear, Nose and Throat (ENT) practices are already being discussed with the multidisciplinary team of the club involved.
\end{abstract}

Descriptors: Malocclusion; Adolescent Development; Open Bite.

\section{Introduction}

Sports players demand much of their bodies and for this reason they must take greater care of their general and oral health. The dentist is able to offer the athletes improvement in their physical performance through the maintenance of oral health, preventing and treating changes in the stomatognathic system. ${ }^{1}$ To do so, it is important that the dentist make a detailed evaluation of the oral condition ${ }^{2}$ to detect, for example, dental malocclusions, ${ }^{3}$ a feature which can compromise greatly the athletes' performance by interfering in chewing and digesting food, thus impairing the absorption of nutrients. It can also lead to loss of muscle balance, headache, problems in the temporomandibular articulation, discomfort and stress. This can make the difference in many competitions, or even 
in an athlete's career. ${ }^{4-8}$

In Brazil, there are many studies about the presence of dental malocclusions ${ }^{9-13}$ and their interference with the general health of the individual, which point out mainly the relationships that exist between malocclusions and alterations in the functions of phonoarticulation and deglutition..$^{14,15}$ The importance of these researched factors to athletic performance is already shown; ${ }^{4,5}$ but studies focusing on young athletes, and the implications of this situation for their physical performance, do not yet exist. For this reason, this study intended to map the situation regarding the stomatognathic dysfunctions of young athletes, focusing on the presence of dental malocclusion. Based on this study, strategies for multidisciplinary planning and intervention, as well as organizing educational lectures, are being adopted in order to present and explain the harm of these dysfunctions to the players, coaches, and professionals involved.

\section{Material and Methods}

84 male athletes (football players) between the ages of 13 and 20 years, who are given housing at the club, were examined in this study. That is, they live on the premises of the Center for Athletic Development (CFA) of Cotia/SP, where they receive professional treatment in the areas of medicine, physiology, physical training, nutrition, psychology and dentistry, in addition to schooling. The free consent form is a standard part of the accommodation agreement, where the parents sign the authorization to investigate any illness that affects the young. This study was submitted to the Ethics Committee of FOUSP under the approval number FR 255627, protocol 75/2009.

The athletes involved in this study have dental records from the CFA dentist responsible for dental monitoring, nevertheless a medical history was taken to observe the oral conditions of the athletes. From there on, we sought to assess the topics for this study. A clinical examination was performed, using wooden spatulas, in which the presence of occlusal disorders was observed, taking the following topics into consideration: Angle's molar relation (without considering the subdivisions); presence of overbite, underbite, overcrowding, abnormal spacing; anterior and posterior open bite; unilateral cross-bite on the right and left sides; bilateral crossbite; midline deviation; facial typology was also observed (mesofacial, dolichofacial, and brachyfacial). The data obtained were recorded in files identified with the name of the athlete, organized and analyzed using percentage. The possible interactions among the variables will be categorized and studied, following disclosure and discussion of the results with the multidisciplinary health team of the SPFC (São Paulo Futebol Clube). This study aimed at identifying the existence of factors that could interfere with the performance of the athletes. There was no concern, at this time, with quantifying or describing them, because each factor will be studied with the participation of the multidisciplinary team.

\section{Results}

In the molar relationship, analyzed according to Angle's classification, $89 \%$ are in Class I, $8 \%$ in Class II, $3 \%$ in Class III.

Of the athletes studied, $9 \%$ showed presence of overbite, $4 \%$ of underbite, $13 \%$ of overcrowding and $21 \%$ of abnormal spacing (Figure 1 ).

Regarding the bite, $11 \%$ presented anterior open bite. Regarding cross-bite, $7 \%$ presented unilateral crossbite on the right side and $2 \%$ unilateral on the left side, $5 \%$ posterior crossbite and $4 \%$ anterior crossbite (Figure 2).

Regarding observations of midline deviation, $4 \%$ presented deviation in the maxilla and 33\% in the mandible.

Regarding facial typology, 39\% are dolichofacial, $4 \%$ brachyfacial and $57 \%$ mesofacial.

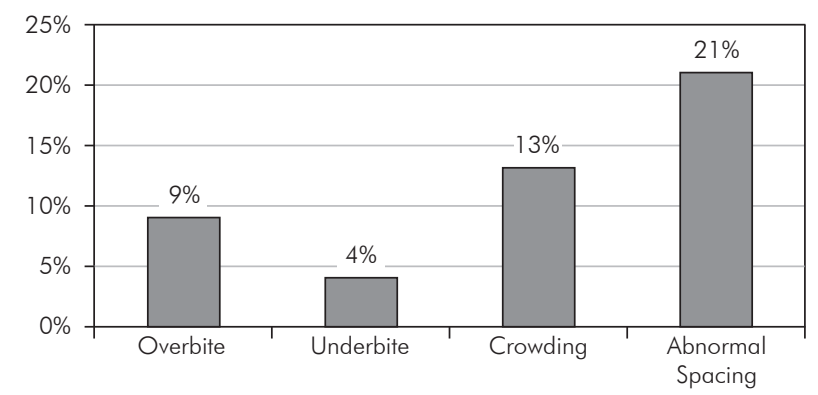

Figure 1 - Frequency of overbite, underbite, crowding, and abnormal spacing (diastema). 


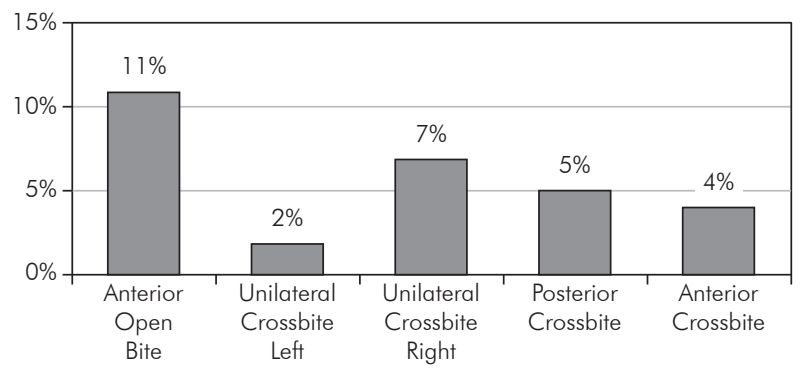

Figure 2 - Frequency of anterior open bite, unilateral crossbite to the right, left, anterior and posterior.

\section{Discussion}

Regarding molar relation, $11 \%$ of the athletes presented malocclusion, which can cause digestive problems and non-absorption of nutrients necessary to attain their highest degree of performance. ${ }^{5}$ When underbite, overbite, abnormal spacing and overcrowding were observed, an overall $47 \%$ occurrence of these factors was found. These can interfere with perfect occlusion, respiration, swallowing, and digestion, in addition to contributing to the occurrence of dental trauma, as other researchers have affirmed. . $3,5,16,17^{2}$

Following the rationale of the factors connected to malocclusion, $29 \%$ of the cases in the group studied were found to have open bite, bilateral or unilateral crossbite equally on the right or the left sides which lead, in addition to the disorders described so far, to postural problems in the athletes having this type of malocclusion. ${ }^{14,15,18}$ The data will be verified by the physiologists and physical therapists from the club's health team. Regarding the presence of midline deviation, a $37 \%$ incidence was found which indicates, according to researchers, the probable presence of some masticatory alteration. ${ }^{19,20}$

On the topic of facial typology (mesofacial, dolichofacial and brachyfacial), a prevalence of $57 \%$ of the mesofacial type can be observed, which was ex-

\section{References}

1. Dias RB, Silva CMF, Coto NP, Pereira SL, Cardim R. Custo e benefício dos protetores bucais em relação a traumas nas práticas esportivas. Rev Odontol UNISA 2003 jan-jun;8(1):60-67.

2. Dias RB, Coto NP. Odontologia deportiva. Rev Int Prothesis Estomatol. 2004;6(4):299-302. pected as this type is prevalent in the Brazilian population. ${ }^{21}$ The dolichofacial type presented in 39\% of the sample; studies were found in the literature which report that dolichofacial patients are the most likely to develop mouth-breathing, as they have nasal and nasopharyngeal structures that are narrower than those of patients of the other facial types. ${ }^{22}$ This fact is currently challenged by another group of researchers, ${ }^{23}$ and for this reason this work attempted to map the existence of malocclusions and, from analyzing the interaction of the assessed factors, this study was careful to involve the specialties connected to each factor since research in the area of Sports Dentistry is still rare in Brasil. Comparisons between types of sports, occurrence of stomatognathic problems and their correlation to withdrawal of the athletes from physical activity must also be considered in further studies.

It must be emphasized that in the club where this research took place, which was the basis for a series of other multidisciplinary and multiprofessional studies, the professionals directly involved with the athletes were interested and each professional, in his/her area, brought questions and suggestions for future studies, showing that dentistry can collaborate with the health of the athlete.

\section{Conclusion}

Based on the results shown, proposals for the implementation of dental, phoniatric, and Ear, Nose and Throat (ENT) practices are already being discussed with the multidisciplinary team of the club involved.

\section{Acknowledgement}

Mr. Marcelo Rodrigues Lima - Technical coordinator of the Departament of Futebol de Base do São Paulo Futebol Clube, São Paulo, SP, Brazil.

\footnotetext{
3. Dias RB, Maia FAS, Coto NP. Odontologia, Arte, Ciência e Técnica. São Paulo: Artes Médicas; 2002. Vol. 2, Capítulo 22, Odontologia desportiva. p. 465-76.
} 
4. Garza J, Baratta R, Odinet K, Metzinger S, Balley D, Best R. Impact tolerances of the rigidly fixated maxillofacial skeleton. Ann Plast Surg. 1993 Mar;30(2):212-6.

5. Dias RB, Coto NP, Silva CMF, Gennari MG. Problemas Odontológicos X Rendimento Desportivo. Rev Odontol Univ Santo Amaro. 2005 Jul-Dez;10(2):28-31

6. Carroll SM, Jawad MA, West M, O’Connor TP. One hundred and ten sports related facial fractures. Br J Sports Med. 1995 Sep;29(3):194-5.

7. Withnall C, Shewchenko N, Gittens R, Dvorak J. Biomechanical investigation of head impacts in football. Br J Sports Med. 2005 Aug;39 Suppl 1:i49-57.

8. Marshall SW, Loomis DP, Waller AE, Chalmers DJ, Bird YN, Quarrie KL, et al. Evaluation of protective equipment for prevention of injuries in rugby union. Int Epidemiol. 2005 Feb;34(1):113-8.

9. Galvão CAAN, Silva WB. Prevalência de maloclusões. Estudo em escolares da cidades de Araçatuba. Ortodontia Paranaense. 1990 Mar-Abr;11(2):79-83.

10. Mascarenhas SC. Freqüência da má-oclusão em escolares de ambos os sexos na faixa etária de 11 a12 anos residentes no município de Palhoça. Ortodontia. 1977;10(1):99-105.

11. Silva Filho OG, Freitas SF, Cavassan AO. Prevalência de oclusão normal e má-oclusão na dentadura mista em escolares da cidade de Bauru (SP). Rev Asso Paul Cir Dent. 1989 NovDez;43(6):287-90.

12. Galvão CAAN, Pereira CB, Bello DRM. Prevalência de maloclusões na América Latina e considerações Antropológicas. Ortodontia. 1994 Jan-Abr;27(1):143-7.

13. Suliano AA, Rodrigues MJ, Júnior AFC, da Fonte PP, PortoCarreiro CF. Prevalência de maloclusão e sua associação com alterações funcionais do sistema estomatognático entre escolares. Cad Saude Publica. 2007 Ago;23(8):1913-23.
14. Rahal A, Krakauer LH. Avaliação e terapia fonoaudiológica com respiradores bucais. Rev Dent Press Ortodon Ortoped Facial. 2001 Jan-Fev;6(1):83-6.

15. Tomita NE, Bijella VT, Franco LJ. Relação entre hábitos bucais e má oclusão em pré-escolares. Rev Saude Publica. 2000 Jun;34(3):299-303.

16. Moreira W. Influência das condições higiênicas e funcionais da cavidade oral na saúde do atleta. Rev Odontol Capixaba. 1975;47(3):27-8.

17. Brin I, Ben-Bassat Y, Heling I, Brezniak N. Profile of an orthodontic patient at risk of dental trauma. Endod Dent Traumatol. 2000 Jun;16(3):111-5.

18. Krakauer LH, Guilherme A. Relação entre respiração bucal e alterações posturais em crianças: uma análise descritiva. Rev Dent Press Ortodon Ortop Maxilar. 2000 Set-Out;5(5):85-92.

19. Sheats RD, McGorray SP, Musmar Q, Wheeler TT, King GJ. Prevalence of orthodontic asymmetries. Semin Orthod 1998 Sep;4(3):138-45.

20. Cardash HS, Ormanier Z, Laufer BZ. Observable deviation of the facial and anterior tooth midlines. J Prosthet Dent. 2003 Mar;89(3):282-5.

21. Gruber KC, Ferreira FV, Cotrim-Ferreira FA, Scavone Júnior H, Carvalho PEG, Quaglio CL. Incidência dos tipos faciais de Ricketts (dolicofacial, mesofacial e braquifacial) nas maloclusões de classe I e classe II divisão $1^{\mathrm{a}}$. J Bras Ortodon Ortop Facial. 2006 Mar-Abr;11(62):180-98.

22. Emslie RD, Massler M, Zwemer JD. Mouth breathing:I. Etiology and effects; a review. J Am Dent Assoc. 1952 May;44(5):506-21.

23. Castro AMA, Vasconcelos MHF. Avaliação da influência do tipo facial nos tamanhos dos espaços aéreos nasofaríngeo e bucofaríngeo . Rev Dent Press Ortodon Ortopedi Facial [citado em 22 jun. 2010] 2008;13(6):43-50.[Disponível em: http://www. scielo.br/pdf/dpress/v13n6/06]. 